\title{
Characteristics of a new reovirus isolated from epizootic ulcerative syndrome infected snakehead fish
}

\author{
K. Riji John",**, M. Rosalind George ${ }^{*}$, R. H. Richards, G. N. Frerichs \\ Institute of Aquaculture, University of Stirling, Stirling FK9 4LA, Scotland, UK
}

\begin{abstract}
Epizootic ulcerative syndrome (EUS) has been infecting a wide range of fishes in the South and Southeast Asia for the last 2 decades. One reovirus-like agent (snakehead reovirus, SKRV), isolated from an EUS-infected snakehead fish and investigated in the present study, is the only reovirus so far isolated from an EUS-infected fish. SKRV was characterised by the presence of a double-stranded RNA genome with icosahedral symmetry and double capsid. The virus had an average size of $71 \mathrm{~nm}$, a buoyant density of $1.36 \mathrm{~g} \mathrm{ml}^{-1} \mathrm{in} \mathrm{CsCl}$ and lacked a lipid-containing envelope. Apart from the above, the presence of a segmented genome and structural proteins falling into 3 specific size classes confirmed that the virus belongs to the family Reoviridae. SKRV differed from aquareoviruses by the lack of a cytopathic effect (CPE) with syncitium formation and in the segmentation pattern of RNA genome. The resistance to $\mathrm{pH}$ (3.0 to 9.0) and heat treatment and inability to multiply in mammalian cell lines and haemagglutinate human ' $\mathrm{O}$ ' red blood cells (RBCs) differentiated SKRV from the rest of the similar genera in the family Reoviridae. Serological comparison indicated the antigenic distinctness of the isolate from selected American and European aquareoviruses. SKRV grew well in SSN-1 and SSN-3 cells at 25 to $30^{\circ} \mathrm{C}$ but not in the most common Aquareovirus susceptible coldwater fish cell line-CHSE-214.
\end{abstract}

KEY WORDS: EUS $\cdot$ Reovirus $\cdot$ Snakehead fish $\cdot$ Characterization

\section{INTRODUCTION}

Epizootic ulcerative syndrome (EUS) has been recognised as the single most potentially damaging disease of fishes in South and Southeast Asia for the last 2 decades. The disease infects a wide variety of fishes, both freshwater and brackishwater species, and snakeheads have by far been the most severely affected fish. A number of infectious agents has been isolated from EUS-infected fish (Roberts et al. 1994). During an investigation of EUS in Thailand, a reoviruslike agent was isolated from an EUS-infected fish following a co-habitation experiment (Roberts et al. 1994).

The family Reoviridae includes non-enveloped, double-stranded RNA viruses, icosahedral in structure, that may appear spherical with a size of 60 to $80 \mathrm{~nm}$ in

\footnotetext{
*Present address: Fisheries College \& Research Institute, Tuticorin 628008, India

**E-mail: rijijohn@vsnl.com
}

diameter and consist of several protein layers surrounding the inner core (Murphy et al. 1995). The precise morphology of the virions varies depending on the genus. Further characteristics consist of 10,11 or 12 segments of linear double-stranded genome depending on the genus with a total $M_{\mathrm{r}}$ (relative molecular ratio) of 12 to $20 \times 10^{6}$. The $M_{\mathrm{r}}$ of these segments range from 0.2 to $3.0 \times 10^{6}$. Fish viruses belonging to the family Reoviridae are of comparatively recent origin compared to many other groups of fish viruses. The family Reoviridae presently has 9 genera, one of which is the new genus Aquareovirus that includes the reoviruses isolated from fish (Murphy et al. 1995). Since the first isolation of a reovirus from golden shiners Notemigonus crysoleucas in 1977 in the USA, more than 30 aquareoviruses have so far been isolated from fish and shellfish worldwide (Lupiani et al. 1996). The present study was aimed at characterisation of a reovirus-like agent recovered from the above-described characteristically EUS-infected snakehead fish. 


\section{MATERIALS AND METHODS}

Viruses and cells. The snakehead reovirus (SKRV or T9231) was isolated from a characteristically EUSinfected striped snakehead fish Channa striata in Thailand during an epizootic in 1992 (Roberts et al. 1994) following a co-habitation trial. EUS was induced in 6 healthy snakehead fish by co-habitation with 6 characteristically EUS-infected snakehead fish. All 6 of the EUS-infected fish died within $5 \mathrm{~d}$ of co-habitation trial. Tail ulcerations were developed in the healthy snakehead fish $12 \mathrm{~d}$ post co-habitation. The ulcerated tissues from the integument and muscles of the tail lesions were sampled for virological examination by inoculating the tissue homogenate onto striped snakehead cells (SSN-1, Frerichs et al. 1991) and bluegill Lepomis macrochirus fry cells (BF-2). The cytopathic effect (CPE) was developed in SSN-1 cells incubated at $25^{\circ} \mathrm{C}$ after $8 \mathrm{~d}$. Virus was further passaged onto fresh SSN-1 cells and CPE observed after $2 \mathrm{~d}$. Stock virus was prepared by growing SKRV in SSN-1 cells and, once CPE was complete, tissue culture fluid was harvested, clarified by centrifugation at $1000 \times g$ for $15 \mathrm{~min}$ and stored at $-70^{\circ} \mathrm{C}$ in aliquots.

Other viruses used in the study for characterization of SKRV were blotched snakehead virus (BSNV, John \& Richards 1999), golden shiner virus (GSV, Plumb et al. 1979) and catfish reovirus (CRV, Amend et al. 1984) from the USA (provided by Dr R. P. Hedrick, School of Veterinary Medicine, University of California, USA) and tench reovirus (TNRV) and chub reovirus (CHRV) (Ahne \& Kolbl 1987) from Europe (provided by Dr W. Ahne, Institute of Zoology and Hydrobiology, University of Munich, Germany).

SSN-1 cells were used for propagation of SKRV. BSNV were inoculated and propagated in SSN-1 or BF-2 cells. GSV was grown on Epithelioma papillosum cyprini (EPC), fathead minnow Pimephales promelas cells (FHM) or chinook salmon Oncorhynchus tshawytscha embryo cells (CHSE-214). Brown bullhead Ictalurus nebulosis cells (BB) were used for propagating CRV. TNRV and CHRV were grown and titrated using EPC or FHM cells. Cells were maintained in Leibovitz-15 (L-15) or Eagle's minimum essential medium (EMEM) (Gibco BRL, Paisley, UK), supplemented with 10\% foetal bovine serum (Gibco BRL). All the cells were maintained at $25^{\circ} \mathrm{C}$ with $5 \% \mathrm{FBS}$ after inoculation with T9231, BSNV, GSV, CRV and at $20^{\circ} \mathrm{C}$ after TNRV and CHRV inoculation.

Purification of the viruses. SKRV was concentrated by ultracentrifugation following propagation of the virus in SSN-1 cells grown in $500 \mathrm{~cm}^{2}$ triple layer flasks (Nunc, Roskilde, Denmark). When CPE was extensive, culture fluid was harvested and clarified by centrifugation at $2000 \times g$ for $30 \mathrm{~min}$ to remove the cellular debris. Supernatant and pelleted cells were then processed separately. Approximately $600 \mathrm{ml}$ of collected supernatant was high speed clarified at $12000 \times g$ for 10 min in an SW-28 rotor in a Beckman L 80 ultracentrifuge (Beckman, Fullerton, CA, USA) before pelleting the virus at $100000 \times g$ for $90 \mathrm{~min}$ in an SW-41 Ti rotor (Beckman). The virus pellets were pooled and resuspended in $2 \mathrm{ml}$ TNE buffer (0.01MTris $\mathrm{HCl}, 0.1 \mathrm{M}-\mathrm{NaCl}, 0.001 \mathrm{M}-\mathrm{EDTA}, \mathrm{pH}$ 7.5). Pelleted cells were resuspended in $4 \mathrm{ml}$ TNE buffer and subjected 3 times to freeze/thawing in liquid nitrogen. Cell associated virus was extracted by treatment with trichlorotrifluroethane (Freon, Sigma, Poole, UK). An equal volume of freon was added to the cell suspension and mixed well using a vortex mixer at full speed for $3 \mathrm{~min}$. After centrifugation at $2000 \times g$ for $10 \mathrm{~min}$, the aqueous phase was removed and freon phase was reextracted using an equal volume of TNE buffer as above. Aqueous phase extracts were pooled and virus pelleted by ultracentrifugation at $100000 \times g$ for $90 \mathrm{~min}$. Pelleted virus was resuspended in $1 \mathrm{ml}$ TNE buffer. Combined virus preparations from culture supernatant and cell pellet were pooled and purified by isopycnic banding in $\mathrm{CsCl}$ gradients.

Polyethylene glycol (PEG, MW 8000, Sigma) was used to concentrate CRV, GSV, TNRV, CHRV and BSNV. CRV was propagated in BB cells by simultaneous inoculation of virus and cells in $500 \mathrm{~cm}^{2}$ triple layer flasks. Tench and chub reoviruses were propagated in the same way in EPC/FHM cells. GSV was grown in preformed, confluent CHSE-214 cells in $175 \mathrm{~cm}^{2}$ flasks after infecting at a multiplicity of infection (MOI) of 0.01 to 0.1 . The virus was allowed to adsorb for $1 \mathrm{~h}$ at room temperature before adding maintenance medium containing antibiotics (50 $\mathrm{IU} \mathrm{ml}^{-1}$ penicillin, $50 \mathrm{\mu g} \mathrm{ml}^{-1}$ streptomycin and $50 \mathrm{\mu g} \mathrm{ml}^{-1}$ kanamycin). BSNV was propagated in preformed monolayers of BF-2 cells as above in $175 \mathrm{~cm}^{2}$ flasks in L-15 medium supplemented with antibiotics.

When the CPE became extensive, remaining cells were scraped into the culture medium and the culture fluid clarified at $2000 \times g$ for $30 \mathrm{~min}$. Cell pellets were freon extracted as described above except that the virus recovered after freon extraction was added to the clarified supernatant without ultracentrifugation or directly overlaid on to the top of a $\mathrm{CsCl}$ gradient. Approximately $800 \mathrm{ml}$ of infected tissue culture fluid was processed for virus concentration using PEG as described earlier (John \& Richards 1999).

Concentrated virus resuspended in TNE was layered on top of a preformed 20 to $40 \%$ discontinuous $\mathrm{CsCl}$ gradient and isopycnically banded by centrifuging at $130000 \times g$ for $17 \mathrm{~h}$ in an SW-41 Ti rotor. The virus bands recovered by side puncturing the centrifuge tubes were pooled and resuspended in TNE buffer and 
repelleted at $100000 \times g$ for $90 \mathrm{~min}$. The purified virus pellet was dissolved in $200 \mu \mathrm{lNE}$ buffer and stored at $-70^{\circ} \mathrm{C}$ until use.

Electron microscopy. SKRV was grown on SSN-1 cells (24 to $48 \mathrm{~h}$ ), fixed in Karnovsky's fixative (Karnovsky 1965) and the cell pellets were held overnight in $0.1 \mathrm{M}$ cacodylate buffer at $4^{\circ} \mathrm{C}$. Following post-fixing in $0.5 \%$ osmium tetroxide for $1 \mathrm{~h}$ and dehydration by acetone, the pellets were impregnated at $60^{\circ} \mathrm{C}$ for $48 \mathrm{~h}$ with epoxy resin (Araldite CY212, Agar Scientific Ltd, Stansted, UK). Ultra thin sections ( $80 \mathrm{~nm}$ ) of cell pellets were cut using a Reichert Ultracut E microtome (Reichert, UK) (Hayat 1989). The sections after staining with uranyl acetate (Watson 1958) and lead citrate (Reynolds 1963) were examined and photographed using a Philips EM 301 transmission electron microscope at $80 \mathrm{kV}$. For negative staining, $5 \mu \mathrm{l}$ of purified virus suspensions was stained by methylamine tungstate. Grids were examined and photographed using the transmission electron microscope at $80 \mathrm{kV}$.

Growth in mammalian cell lines. The ability of SKRV to multiply in mammalian cells was determined by using BHK-21 (baby hamster kidney) and Vero (green monkey kidney) cell lines. BHK-21 cells were grown in EMEM and incubated at 25 and $37^{\circ} \mathrm{C}$. Vero cells were maintained in DMEM (Dulbecco's modified Eagle's medium, Sigma) with $10 \%$ FBS and antibiotics (50 IU ml ${ }^{-1}$ penicillin, $50 \mathrm{\mu g} \mathrm{ml}^{-1}$ streptomycin, $50 \mu \mathrm{g}$ $\mathrm{ml}^{-1}$ kanamycin and amphotericin $2.5 \mu \mathrm{g} \mathrm{ml}^{-1}$ ) at $37^{\circ} \mathrm{C}$. Flasks were observed for the development of CPE for $7 \mathrm{~d}$ after inoculation of SKRV and negative flasks were subcultured once and monitored for a further 6 to $10 \mathrm{~d}$ for the development of CPE.

Biophysical and biochemical characteristics. The type and nature of nucleic acid of SKRV were analysed using a DNA inhibitor, 5-ido-2 deoxyuridine (IUDR) and acridine orange staining (Rovozzo \& Burke 1973). Resistance of SKRV to chloroform treatment was tested according to the method of Feldman \& Wang (1961). SKRV was tested for the ability to withstand heat treatment at $56^{\circ} \mathrm{C}$ for $2 \mathrm{~h}$ and $\mathrm{pH}$ treatment at $\mathrm{pH} 3$ and 9 for $30 \mathrm{~min}$. Density of the virions were found out following isopycnic centrifugation of semipurified virus in caesium chloride gradient as before. At the end of the run, fractions were collected using a Beckman fraction recovery system (Beckman). The refractive index of each fraction was determined using an ABBE refractometer (Bellingham \& Stanley Ltd, Kent, UK) after titrating the fractions in SSN-1 cells. The density and titre of each fraction were plotted against the respective number of fractions and the density of virions was extrapolated from the graph against fractions that gave the highest titre.

Analysis of structural proteins. Structural proteins of SKRV were analysed by SDS-polyacrylamide gel electrophoresis (PAGE) using a BRL Mini-V 80 system (BRL Life Technologies UK Ltd, UK) along with BSNV, CRV, GSV, TNRV, CHRV and broad range molecular weight standards (BioRad, Richmond, CA, USA). Structural proteins of the viruses were resolved by discontinuous polyacrylamide-SDS slab gels (Laemmli 1970 ) of $10 \%$ acrylamide prepared according to the general procedures of Hames \& Rickwood (1990). Electrophoresis was conducted at $200 \mathrm{~V}$ and $200 \mathrm{~mA}$ for 45 to $55 \mathrm{~min}$ and the gels were stained in $0.1 \%$ Coomassie brilliant blue. Molecular weights of the virion proteins were determined according to the method of Hames \& Rickwood (1990).

Analysis of nucleic acids. Nucleic acid from purified virions was extracted using Proteinase K-SDS digestion and phenol-chloroform extraction according to Burleson et al. (1992). RNA present in the solution was quantified by measuring the optical density in an Ultrospec UV spectrophotometer (Pharmicia Biotech, Sweden) at $260 \mathrm{~nm}$.

Viral RNA was analysed by agarose gel electrophoresis according to Sambrook et al. (1989) with minor modifications. Agarose gels of Seakem agarose $(1.5 \%)$ (Flowgen, Leicestershire, UK) and Metaphor agarose $(3 \%)$ (Flowgen) were prepared in MOPS buffer (0.2 M 3-N-morpholino-2-hydroxypropane sulfonic free acid, $0.05 \mathrm{M}$ sodium acetate, 0.005 M EDTA, $\mathrm{pH}$ 7.0) with formaldehyde. Viral RNA samples and molecular mass markers (RNA molecular mass markers II and III, Boehringer Mannheim, Germany) were electrophoresed on a horizontal gel electrophoresis apparatus (Pharmicia Biotech) at 1 or $1.5 \mathrm{~V} \mathrm{~cm}^{-1}$ (14 to $20 \mathrm{~h}$ ). The gels were stained in $1 \mathrm{\mu g} \mathrm{ml}^{-1}$ ethidium bromide for $30 \mathrm{~min}$ and destained in DEPC (diethylpyrocarbonate, BDH, Poole, UK) treated deionised water before photographing using Polaroid films or scanning using Gel Works advanced ID software on a Gel-doc system (UVP, UK). Molecular weights of the viral RNA bands were calculated from a semi-logarithmic standard curve of molecular weights plotted against migration distance of the markers.

Serological studies. The ability of SKRV haemagglutinate human 'O' type erythrocytes (Sigma) was determined by the method of Kuchler (1977). Polyclonal rabbit antiserum against the viruses was prepared in New Zealand white rabbits as described by Lilley \& Frerichs (1994). Cross-neutralising activity of the antisera of SKRV, CRV, GSV and CHRV was tested by the $\alpha$ procedure against SKRV, CRV, GSV, TNRV and CHRV (Rovozzo \& Burke 1973). Briefly, all viruses were 10fold serially diluted and mixed with equal volumes of the antisera at appropriate dilutions. Mixtures were incubated in 96-well plates at room temperature for $60 \mathrm{~min}$ and $100 \mu \mathrm{l}$ of appropriate single cell suspension in maintenance medium was added. The plates were 
then incubated at appropriate temperatures and monitored for CPE over $10 \mathrm{~d}$ and neutralisation indices were calculated as the ratio of the virus titre without antiserum to the virus titre in the presence of antiserum.

\section{RESULTS}

\section{Cytopathology}

The CPE of SKRV in SSN-1 were compared with the CPE of aquareoviruses. SKRV did not produce typical syncitia with multiple nuclei in SSN-1 cells similar to those found in other aquareoviruses in the respective cell lines (Fig. 1). SKRV infection in SSN-1 cells progressed with the formation of focal areas of cell destruction in the monolayer due to aggregation and rounding up of granular refractile cells forming cell clumps. CPE in the form of holes in the cell sheet usually progressed for about 6 to $10 \mathrm{~d}$ to involve the entire monolayer, at which time the cells in clumps became detached from the substrate, leaving a few still attached to the culture surface. SKRV was unable to grow and cause any CPE in the most common aquareovirus susceptible coldwater fish cell line, CHSE-214, and in both BHK-21 and Vero cells during the period of observation.

\section{Electron microscopy}

Like other aquareoviruses, SKRV particles had icosahedral symmetry with double capsid structure. The virions in cell culture had an overall diameter of $68 \pm 1.8 \mathrm{~nm}$ with a size range of 62 to $77 \mathrm{~nm}(\mathrm{n}=19)$. Characteristic cytoplasmic inclusion bodies of variable size and shapes (some reaching a length of $3.6 \mu \mathrm{m}$ ) with relatively electron-dense areas of granular matrix were found scattered in the cytoplasm without any special membranous envelope at different stages of virus formation. Some of the viroplasms were found to be fully formed with a paracrystalline array of virus particles filling the entire area of the inclusion body (Fig. 2).

Unenveloped spherical particles having a mean diameter of $71 \pm 1.2 \mathrm{~nm}$ (range 64 to $77 \mathrm{~nm}, \mathrm{n}=18$ ) and double capsid structure were observed in the negatively stained preparations of SKRV (Fig. 3). The virions had an inner diameter of 43 to $48 \mathrm{~nm}$ and capsid thickness of 12 to $15 \mathrm{~nm}$. Morphologically, SKRV was similar to the other aquareoviruses CRV, GSV, TNRV and CHRV.

\section{Biophysical and biochemical characteristics}

Lack of inhibition of SKRV in SSN-1 cells growing in $50 \mu \mathrm{g} \mathrm{ml}^{-1}$ IUDR-incorporated culture medium and the presence of yellowish green cytoplasmic inclusions following acridine orange staining of virus-infected cell cultures indicated the presence of a double-stranded

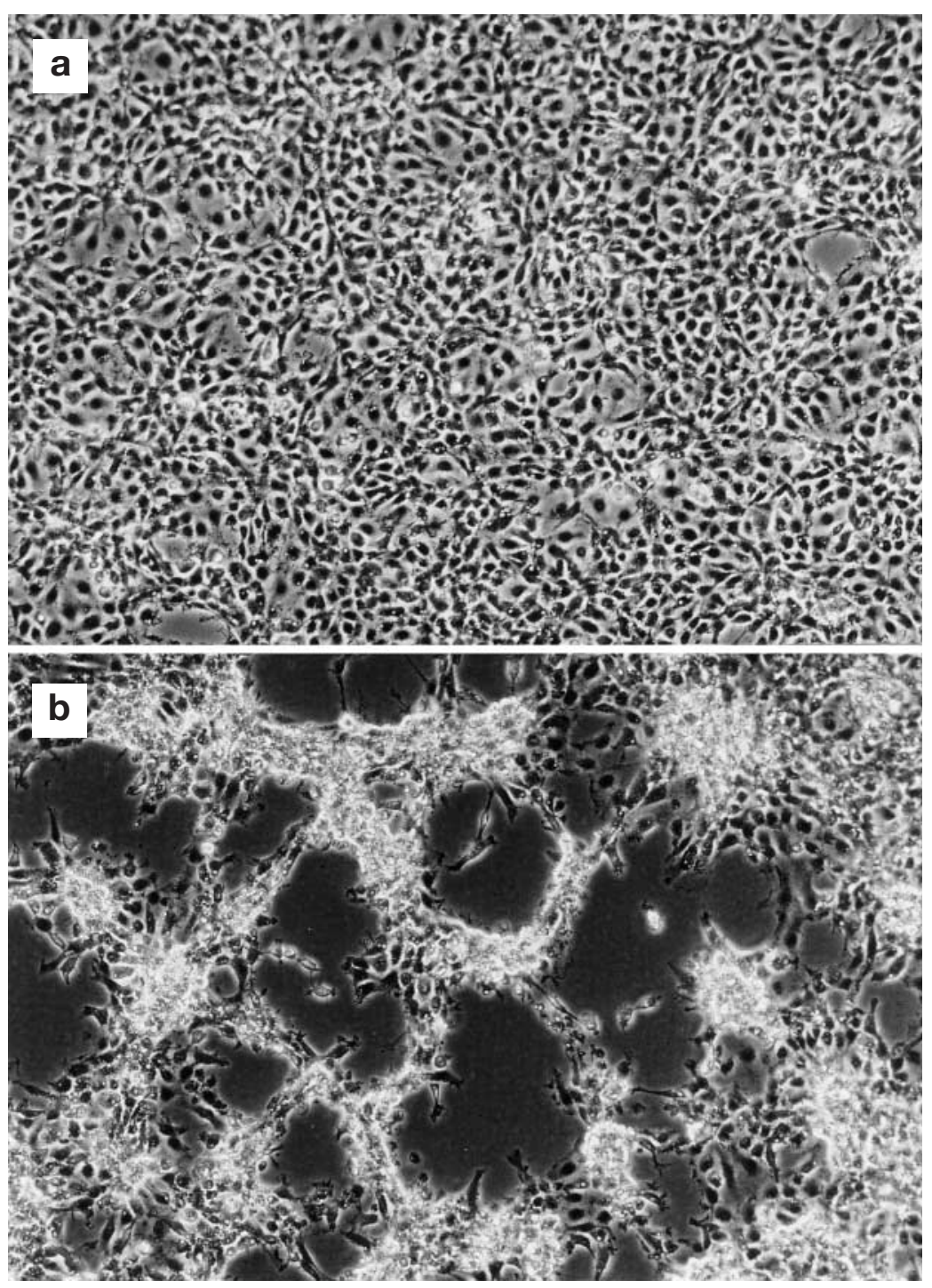

Fig. 1. (a) Normal SSN-1 monolayer. (b) SKRV growing in SSN-1 cells showing formation of focal areas of cell destruction in the monolayer due to aggregation and rounding up of granular refractile cells forming cell clumps 


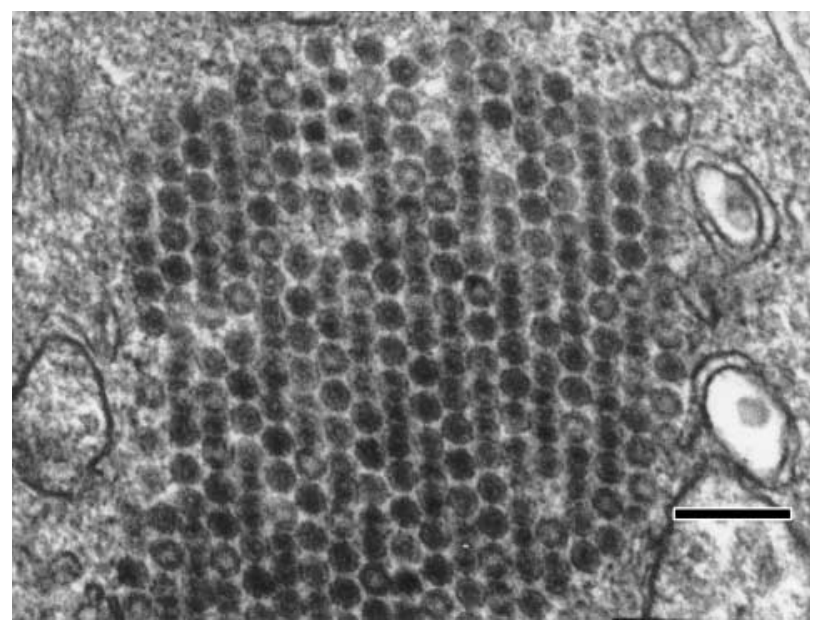

Fig. 2. Electron micrograph of SKRV in SSN-1 cells. Virions filling the entire viroplasm towards the late morphogenesis of SKRV in SSN-1 cells. Scale bar $=300 \mathrm{~nm}$

RNA genome (Rovozzo \& Burke 1973). Infectivity resistance to chloroform treatment confirmed the absence of a lipid-containing envelope (Feldman \& Wang 1961). SKRV was resistant to heat treatment at $56^{\circ} \mathrm{C}$ for $2 \mathrm{~h}$ and was also stable at acid (3.0) and alkaline (9.0) pH for 30 min (Rovozzo \& Burke 1973). Isopycnic centrifugation of pelleted virus at $130000 \times g$ for $17 \mathrm{~h}$ in 20 to $40 \%$ discontinuous $\mathrm{CsCl}$ gradient and assay of recovered fractions in SSN-1 cells established a buoyant density of $1.36 \mathrm{~g} \mathrm{ml}^{-1}$ for infective particles.

\section{Analysis of structural proteins}

Polypeptide composition of SKRV was similar to other American and European aquareoviruses CRV, GSV, TNRV and CHRV (Fig. 4, Table 1). Structural proteins of SKRV were resolved into 5 components falling into 3 size classes (large, medium and small) of polypeptides characteristic of the family Reoviridae. Estimated molecular masses of the proteins of SKRV were as follows: VP1 $=154, \mathrm{VP} 2=140, \mathrm{VP} 3=65$, VP4 $=$ 47 and VP5 $=38 \mathrm{kDa}$.

\section{Analysis of nucleic acids}

The electropherotype of genomic RNAs of all the viruses analysed fell into the general nucleic acid organisation pattern of the family Reoviridae, having 3 size classes of genomic segments (Fig. 5a). The RNA of SKRV analysed for $20 \mathrm{~h}$ in $3 \%$ Metaphor agarose gel further resolved the small genomic segments (Fig. 5b). Estimated molecular masses of the SKRV genome segments are shown in Table 2 . Unlike the 3 aquareoviruses CRV, GSV and TNRV, smaller segments of SKRV RNA did not resolve into 5 components characteristic of the genus Aquareovirus. The smallest RNA segment of SKRV had an estimated molecular mass of $0.67 \times 10^{6}$ whereas the smallest segments of CRV and GSV were 0.54 and $0.52 \times 10^{6}$ respectively (as obtained in the present study). Comparative analysis of the electropherotype of SKRV with that of CRV, GSV and TNRV indicated that the SKRV genome probably contains only 10 RNA segments that ranged in molecular mass from $2.93 \times 10^{6}(4.39 \mathrm{kbp})$ to $0.67 \times 10^{6}(1.01 \mathrm{kbp})$ Da. The total molecular mass of the SKRV genome was approximately $16.38 \times 10^{6}$ (24.56 kbp).

\section{Serological characteristics}

SKRV, GSV and CRV were tested for their capacity to haemagglutinate human 'O' type red blood cells (RBC). At a final dilution of $1 \%$ RBC after addition of virus, none of the tested virus isolates showed agglutination of human ' $\mathrm{O}$ ' erythrocytes at room temperature, $25^{\circ} \mathrm{C}$.

Neutralisation indices (NI) of the test involving antiserum against SKRV, GSV, CRV and CHRV and respective viruses and TNRV showed specificity of SKRV antisera evident from the high homologous NI and little cross reaction with any of the other viruses tested (Table 3). SKRV was also not neutralised by any of the other antisera tested. Results from the cross neutralisation studies indicated that SKRV is antigenically unrelated to the American and European aquareovirus isolates GSV, CRV, TNRV and CHRV.

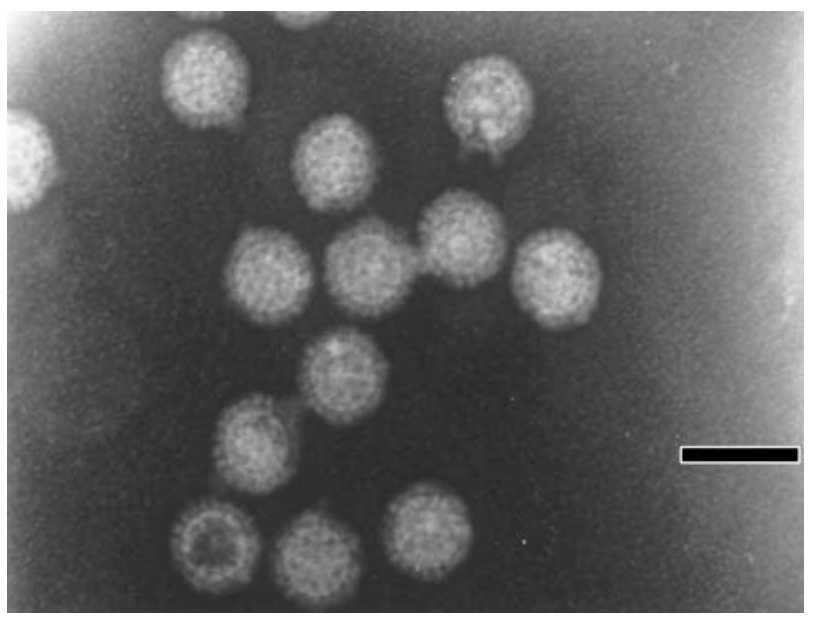

Fig. 3. Purified SKRV negatively stained with methylamine tungstate. Distinct double capsid layers are visible. Scale bar $=100 \mathrm{~nm}$ 


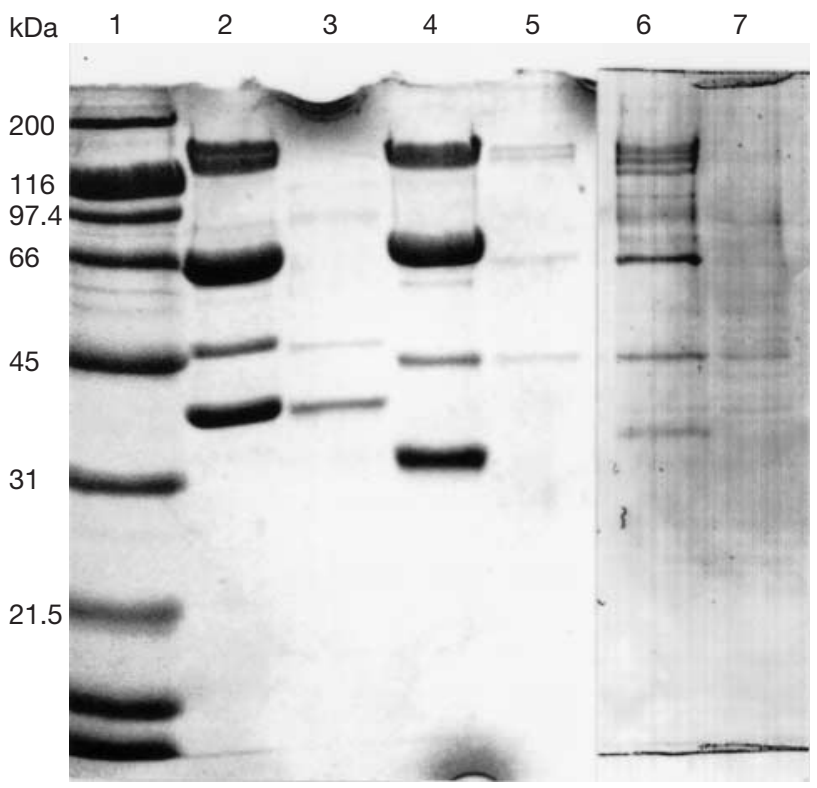

Fig. 4. SDS-PAGE analysis of structural proteins of SKRV in $10 \%$ acrylamide gel stained with $1 \%$ Coomassie blue. Lane 1 : broad range molecular mass markers (BioRad); lane 2: SKRV; lane 3: BSNV; lane 4: CRV; lane 5: GSV; lane 6: TNRV; lane 7: CHRV
Table 1. Estimates of molecular mass of viral structural proteins of SKRV, reovirus type 3 and selected aquareoviruses. SKRV was analysed by SDS-PAGE in $10 \%$ acrylamide concentration

\begin{tabular}{|lccccc}
\hline \multirow{2}{*}{ Virus } & \multicolumn{5}{c}{ Virus polypeptides (molecular mass in kDa) } \\
& VP1 & VP2 & VP3 & VP4 & VP5 \\
\hline Reo 3 $^{\mathrm{a}, \mathrm{b}}$ & $155-\lambda 1$ & $140-\lambda 2$ & $72-\mu 1 \mathrm{c}$ & $38-\sigma 2$ & $34-\sigma 3$ \\
Reo 3, $^{\mathrm{c}, \mathrm{b}}$ & $137 / 143-\lambda 1$ & $145-\lambda 2$ & $72-\mu 1 \mathrm{c}$ & $47-\sigma 2$ & $41-\sigma 3$ \\
SKRV $^{\mathrm{d}}$ & 154 & 140 & 65 & 47 & 38 \\
CRV $^{\mathrm{e}}$ & 132 & 130 & 70 & 43 & 32 \\
GSV $^{\mathrm{e}}$ & 137 & 130 & 63 & 44 & 36 \\
13P2 $^{\mathrm{e}}$ & 135 & 128 & 70 & 45 & 33 \\
$\mathrm{CSV}^{\mathrm{e}}$ & 137 & 126 & 72 & 44 & 34 \\
AFRV $^{\mathrm{f}}$ & 137 & 127.7 & 73.5 & 44.2 & 34.4 \\
SRV $^{\mathrm{g}}$ & 145 & 128 & 60 & 40 & 36 \\
LSV $^{\mathrm{h}}$ & 139 & 130 & 69 & 44 & 34 \\
SBR $^{\mathrm{i}, \mathrm{j}}$ & 130 & 127 & $71(\mathrm{VP} 5)$ & 46 (VP6) & 35 (VP7) \\
\hline
\end{tabular}

${ }^{\mathrm{a}}$ From Joklik (1983a) ${ }^{\mathrm{b}}{ }^{\mathrm{v}}$ virion proteins $\leq 2 \%(\lambda 3-135, \mu 1-80$, $\mu 2-70$ and $\sigma 1-42 \mathrm{kDa}$ ) not included; ${ }^{c}$ from Nibert et al. (1996); ${ }^{d}$ from the present study; ${ }^{\mathrm{e}}$ from Winton et al. (1987); ${ }^{\mathrm{f}}$ from Varner \& Lewis (1991; 61.2 protein not included);

${ }^{\mathrm{g}}$ Marshall et al. (1990), ${ }^{\mathrm{h}}$ from Hsu et al. (1989); ${ }^{\mathrm{i}}$ Samal et al. (1991b); ${ }^{\mathrm{j}}$ Subramanian et al. (1994) (2 additional minor proteins [VP3-126 kDa, VP4-73 kDa] also reported)

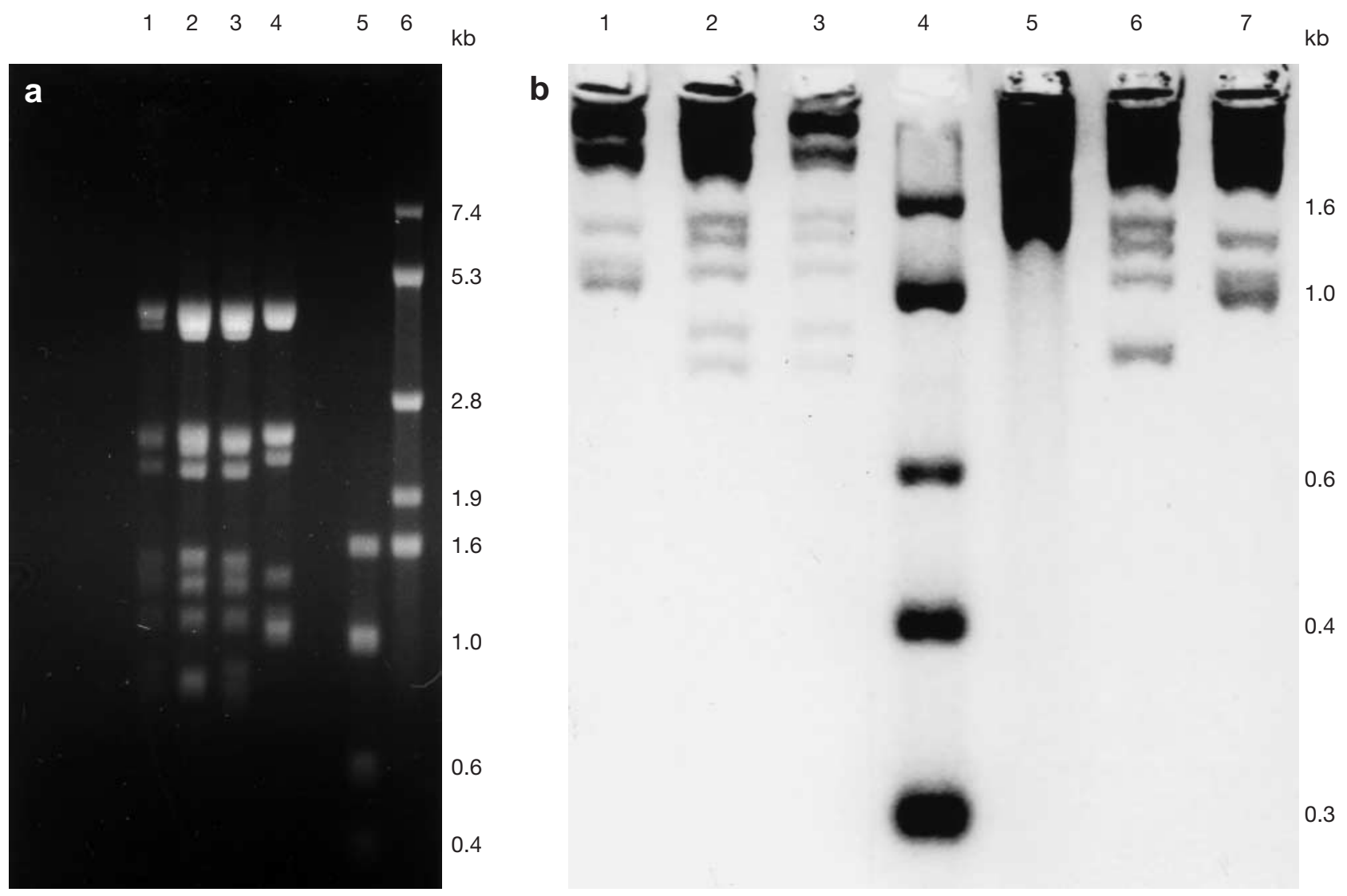

Fig. 5. Comparative analysis of 4 viral RNA in (a) $1.5 \%$ Seakem agarose and (b) $3 \%$ Metaphor agarose gel. Electrophoresis was carried out for (a) 14 and (b) for $20 \mathrm{~h}$ at $1 \mathrm{~V} \mathrm{~cm}^{-1}$ and stained in $1 \mu \mathrm{g} \mathrm{ml}^{-1}$ ethidium bromide for $30 \mathrm{~min}$. (a) Lane 1: TNRV; lane 2: CRV; lane 3: GSV; lane 4: SKRV; lane 5: RNA molecular mass marker II; and lane 6: RNA molecular mass marker III (Boehringer Mannheim). (b) Lanes 1 and 7: SKRV (1/3 RNA more in lane 7); lane 2: GSV; lane 3: TNRV; lanes 4 and 5: RNA molecular mass marker II and III; lane 6: CRV (negative image) 
Table 2. Estimated molecular mass of RNA segments of SKRV analysed in $1.5 \%$ agarose gels. Molecular masses of segments were calculated from semi-logarithmic plot of molecular weight versus migration distance of the markers

\begin{tabular}{|c|c|c|c|c|c|}
\hline \multirow{3}{*}{$\begin{array}{l}\text { Segment } \\
\text { L1 }\end{array}$} & \multicolumn{5}{|c|}{ Molecular mass $\times 10^{-6}$} \\
\hline & \multirow{2}{*}{$\begin{array}{r}\text { SKRV } \\
2.93^{b}\end{array}$} & \multirow{2}{*}{$\frac{\mathrm{CRV}^{\mathrm{a}}}{2.40}$} & \multirow{2}{*}{$\frac{\text { GSV }^{\mathrm{a}}}{2.50}$} & \multicolumn{2}{|c|}{ Reovirus type 3} \\
\hline & & & & $2.50^{\mathrm{c}}$ & $2.70^{\mathrm{d}}$ \\
\hline L2 & 2.83 & 2.40 & 2.40 & 2.40 & 2.60 \\
\hline L3 & 2.78 & 2.30 & 2.20 & 2.30 & 2.50 \\
\hline M1 & 1.69 & 1.60 & 1.60 & 1.60 & 1.80 \\
\hline M2 & 1.65 & 1.50 & 1.50 & 1.60 & 1.70 \\
\hline M3 & 1.51 & 1.30 & 1.40 & 1.40 & 1.60 \\
\hline S1 & 0.88 & 0.90 & 0.90 & 0.92 & 1.10 \\
\hline S2 & 0.74 & 0.88 & 0.80 & 0.76 & 0.85 \\
\hline S3 & 0.71 & 0.61 & 0.66 & 0.64 & 0.76 \\
\hline $\mathrm{S} 4$ & 0.67 & 0.41 & 0.40 & 0.61 & 0.71 \\
\hline S5 & - & 0.40 & 0.35 & - & - \\
\hline Total & 16.38 & 14.70 & 14.71 & 14.73 & 16.32 \\
\hline
\end{tabular}

\section{DISCUSSION}

SKRV used in the present study was a single reovirus-like agent isolated from a characteristically EUS-infected striped snakehead fish. The nature of cytopathology induced by SKRV in homologous SSN-1 cells was different from the typical syncitia formation caused by aquareoviruses in respective cell lines (Winton 1989, Hetrick et al. 1992). The CPE of SKRV in SSN-1 cells, which was characterised by focal areas of cell destruction in the monolayer due to aggregation and rounding up of granular refractile cells forming cell clumps and lack of a plaque-like syncitium formed out of cell fusion, was similar to the CPE induced by mammalian reoviruses in cell cultures (Gomatos et al. 1962). Multiplication of cells escaping lytic infection resulting in regeneration of the monolayer after SKRV infection was observed occasionally in SSN-1 cells. A

Table 3. Cross-neutralisation indices among SKRV, GSV, CRV, CHRV and TNRV. Neutralisation indices (NI) expressed as logarithmic difference in virus titres in the presence and absence of antiserum. NI values equal to or greater than 1.7 indicate serological similarity. Dilution of antiserum used in the test given in parentheses

\begin{tabular}{|lcccc|}
\hline \multirow{2}{*}{$\begin{array}{l}\text { Virus } \\
\text { strain }\end{array}$} & SKRV(1/100) & GSV(1/50) & CRV(1/50) & CHRV(1/50) \\
\hline SKRV & $\mathbf{7 . 5}$ & 0 & 0 & 0 \\
GSV & 0 & $\mathbf{5 . 4 5}$ & 2.10 & 5.30 \\
CRV & 0.17 & 0.50 & $\mathbf{3 . 4 9}$ & 1.50 \\
TNRV & 0 & 5.58 & 2.44 & 5.75 \\
CHRV & 0 & 5.30 & 2.79 & $\mathbf{5 . 3 0}$ \\
& & & & \\
\hline
\end{tabular}

similar observation was reported in the case of GSV in FHM cells (Plumb et al. 1979) and turbot reovirus in EPC cells (Lupiani et al. 1989). The refractory nature of Vero and BHK-21 cell lines to SKRV infection indicated the host specificity of the virus, which helps to differentiate it from reoviruses of mammalian origin (Rosen et al. 1979, Joklik 1983c) and orbiviruses (Gorman et al. 1983). Aquareoviruses were also, in general, found unable to grow in cells of mammalian or avian origin (Meyers 1979, Hsu et al. 1989, Samal et al. 1990, Dopazo et al. 1991).

Electron microscopic studies indicated that $71 \mathrm{~nm}$ size and icosahedral structure of SKRV are similar to those of aquareoviruses (Plumb et al. 1979, Winton et al. 1981, Amend et al. 1984, Ahne \& Kolbl 1987, Lupiani et al. 1989, Samal et al. 1990, Varner \& Lewis 1991) and mammalian reovirus of the genus Orthoreovirus (Joklik 1983c). Studies on the nucleic acid using halogenated pyrimidine IUDR and acridine orange staining indicated the presence of a double-stranded RNA genome (Rovozzo \& Burke 1973). Lack of a lipid-containing envelope and double-stranded RNA genome of SKRV are the typical characteristics of the family Reoviridae (Joklik 1983b).

Resistance to heat treatment at $56^{\circ} \mathrm{C}$ for up to $2 \mathrm{~h}$ has shown the similarity of SKRV to orthoreoviruses (Drayna \& Fields 1982). Unlike orthoreoviruses, heating to $60^{\circ} \mathrm{C}$ rapidly inactivates the orbiviruses (Murphy et al. 1995). Aquareoviruses exhibit variations in the sensitivity to heat treatment (Plumb et al. 1979, Winton et al. 1981, Chen \& Jiang 1984, Lupiani et al. 1989, Varner \& Lewis 1991). Reoviruses are also characterised by their resistance to $\mathrm{pH}$, which varies among different genera (Murphy et al. 1995). Of the 5 different genera of reoviruses infecting vertebrates (Orthoreovirus, Orbivirus, Rotavirus, Aquareovirus and Coltivirus), orbiviruses and coltiviruses are characterised by a loss of infectivity at low $\mathrm{pH}$ in contrast to the stability of reoviruses at low $\mathrm{pH}$ (Gorman et al. 1983). Avian reovirus strains are also resistant to $\mathrm{pH} 3.0$ treatment (Kawamura et al. 1965). Aquareoviruses are generally stable over a wide pH range (Meyers 1979, Plumb et al. 1979, Winton et al. 1981, Chen \& Jiang 1984, Ahne \& Kolbl 1989, Lupiani et al. 1989, Varner \& Lewis 1991). Rotaviruses vary in their stability to $\mathrm{pH}$ treatment (Holmes 1983). Retention of infectivity by SKRV after heat and $\mathrm{pH}$ treatment shows that it is characteristically similar to the vertebrate members of the family Reoviridae (except orbiviruses and coltiviruses). As is typical of the members of the family Reoviridae which have vertebrate hosts, complete virions of SKRV had a buoyant density of $1.36 \mathrm{~g} \mathrm{ml}^{-1}$ in $\mathrm{CsCl}$ (Smith et al. 1969, Holmes 1983). Buoyant density of complete virions of aquareoviruses was also reported to range from 1.34 to $1.36 \mathrm{~g} \mathrm{ml}^{-1}$ (Winton et al. 1987, Hsu et al. 1989, Varner \& Lewis 1991). 
Structural proteins of SKRV were resolved into 3 size classes characteristic of the family Reoviridae (Joklik 1983c). Although the electropherotype of SKRV in SDS-PAGE was similar to other aquareoviruses, individual molecular masses of the $\lambda$ class polypeptides were slightly different. SKRV had 5 structural polypeptides of molecular mass ranging from 154 to $38 \mathrm{kDa}$ with 2 large ( $\lambda 1$ and $\lambda 2), 1$ medium $(\mu 1)$ and 2 small $(\sigma 1$ and $\sigma 2)$ virus structural proteins. Comparable electrophoretic profiles with the structural proteins falling into 3 size classes $(\lambda, \mu$ and $\sigma)$ with similar molecular mass ranging from 145 to $32 \mathrm{kDa}$ were present in aquareoviruses (Hedrick et al. 1984, Winton et al. 1987, Hsu et al. 1989, Marshall et al. 1990, Samal et al. 1990, 1991a).

Although a detailed study of the gene coding assignments and radiolabelling of viral proteins would be required to completely characterise the structural and non-structural proteins of SKRV, with the available information on viral polypeptides of orthoreoviruses with a similar genomic segmentation pattern, SKRV structural proteins were found similar to the existing classification pattern of the proteins of mammalian reoviruses. Virions of reovirus type 3 Dearing strain consists of 9 polypeptide species distributed in 3 size classes having a molecular mass ranging from 155 to $34 \mathrm{kDa}$ (Joklik 1983c). Later studies have found that the molecular mass of the reovirus structural proteins ranged from 145 to $41 \mathrm{kDa}$ (Nibert et al. 1996). Of the 9 structural proteins, 4 polypeptides were present in the virions in less than $2 \%$ each. Investigations of striped bass aquareovirus polypeptides and gene coding assignments have identified the presence of 7 structural polypeptides and 5 non-structural polypeptides associated with the virus (Subramanian et al. 1994).

Among the 5 structural proteins of SKRV, $\mu 1$ (65 kDa) and $\sigma 2(38 \mathrm{kDa})$ are present in the highest concentrations. Proteins of the same size groups make up more than $60 \%$ of the mass of the reovirus type 3 Dearing strain and form the major structural proteins of the Orthoreovirus capsid (Smith et al. 1969). Similar size proteins (VP3 and VP5) also form the major structural proteins present in larger quantities in many aquareoviruses (Winton et al. 1987, Samal et al. 1991a). The nature of polypeptide composition of SKRV is different from orbiviruses that have 4 major and 3 minor polypeptides (Gorman 1979, Roy 1996) and rotaviruses which contain 8 structural proteins (VP1 to VP8) (Kalica \& Theodore 1979, Estes 1996).

Comparative RNA analysis of SKRV with GSV, CRV and TNRV has shown the characteristically segmented pattern of the SKRV genome falling into 3 size classes, large, medium and small segments. Among the different genera of the family Reoviridae, orthoreoviruses, orbiviruses, fijiviruses, cypoviruses and oryzaviruses are the 5 genera typified by the presence of 10 dsRNA segments. Rotaviruses and aquareoviruses have 11 dsRNA segments in their genome while coltiviruses and phytoreoviruses have a 12-segmented pattern of genomic organisation. Of the 5 genera of reoviruses having 10 dsRNA genomic segments, cypoviruses are isolated only from arthropods while fijiviruses and oryzaviruses are from plants. Comparison of the electropherotype of SKRV and the aquareoviruses indicated that SKRV probably do not have 5 small dsRNA segments characteristic of the genus aquareoviruses (Fig. 5b). However, the large and medium size classes of RNA segments were comparable to the aquareovirus genome, indicating the presence of 3 segments each in the large and medium size classes (Fig. 5a), bringing the likely total number of segments of SKRV to 10. Although a comparative study could not be undertaken with a typical 10-segmented reovirus (orthoreoviruses) in an SDS-PAGE system, from published reports (Gorman et al. 1983, Joklik 1983c, Hedrick et al. 1984, Winton et al. 1987, Samal et al. 1991a, Nibert et al. 1996), it could be inferred that the SKRV electropherotype has close similarity with that of the reovirus type 3 Dearing strain. The strength of the bands was also taken into consideration in drawing this conclusion, as the purified virions are reported to contain equimolar quantities of these 10 species of doublestranded RNA segments (Shatkin et al. 1968). The total size and $M_{\mathrm{r}}$ of the SKRV genome $\left(16.38 \times 10^{6}\right.$, $24.56 \mathrm{kbp}$ ) are similar to that of the reovirus prototype strain T3D (type 3 Dearing) which has a total size of 23549 bp (Wiener \& Joklik 1989). Genome size of SKRV was, however, different from the orbiviruses, which has a total genome length of only $19.2 \mathrm{kbp}$ and molecular mass of $13 \times 10^{6}$ (Roy 1996).

Similar to avian reoviruses, SKRV also differs from mammalian reoviruses in their inability to haemagglutinate human 'O' RBC erythrocytes (Kawamura et al. 1965, Joklik 1983c). One of the evident characters that differentiated SKRV from avian reoviruses bearing similar characteristics was the absence of syncitium formation in the cell lines infected with SKRV. A complete lack of antigenic relatedness between SKRV and the aquareovirus isolates in the $\alpha$-cross neutralisation study indicates that SKRV shares no common neutralising epitopes with aquareoviruses and shows the generic difference between them (Ginsberg 1988). Since we do not have a polyacrylamide gel of the viral RNA to unambiguously prove the presence of a 10segmented genome for the SKRV, this isolate could be considered as a new strain of Aquareovirus at present. However, if this isolate does contain only10 RNA segments, SKRV would be the first report of the isolation of a reovirus from a poikilothermic host that belongs to the genus Orthoreovirus. 
Acknowledgements. The authors are thankful to Ms Marguerite Kobs for her help with electron microscopy and to Ms Fiona Muir and Alison Tweedie for technical assistance. K.R.J. is the recipient of a Commonwealth Scholarship from the Commonwealth Scholarship Commission, London.

\section{LITERATURE CITED}

Ahne W, Kolbl O (1987) Occurrence of reoviruses in European cyprinid fishes (Tinca tinca Lin.; Leuciscus cephalus Lin.). J Appl Ichthyol 3(3):139-141

Ahne W, Kolbl O (1989) Some properties of reoviruses isolated from tench (Tinca tinca) and chub (Leuciscus cephalus). In: Ahne W, Kurstak E (eds) Viruses of lower vertebrates. Springer-Verlag, Heidelberg, p 250-256

Amend DF, McDowell T, Hedrick RP (1984) Characteristics of a previously unidentified virus from channel catfish (Ictalurus punctatus). Can J Fish Aquat Sci 41(5):807-811

Burleson FG, Chambers TM, Wiedbrauk DL (1992) Virology: a laboratory manual. Academic Press, London

Chen Y, Jiang Y (1984) Morphological and physico-chemical characterization of the hemorrhagic virus of grass carp. Kexue Tongbao 29(6):832-835

Dopazo CP, Lupiani B, Rivas C, Novoa B, Barja JL, Toranzo AE (1991) Influence of the temperature and cell line on the adsorption and replication of five fish rotaviruses. Gyobyo Kenkyu 26(4):169-175

Drayna D, Fields BN (1982) Genetic-studies on the mechanism of chemical and physical inactivation of reovirus. J Gen Virol 63(11):149-159

Estes ME (1996) Rotaviruses and their replication. In: Fields BN, Knipe DM, Howely PM, Chanock RM, Melnick JL, Monath TP, Roizman B, Straus SE (eds) Fields virology, Vol 2, 3rd edn. Lippincott-Raven, Philadelphia, p 1625-1655

Feldman H, Wang S (1961) Sensitivity of various viruses to chloroform. Proc Soc Exp Biol Med 106:736-738

Frerichs GN, Morgan D, Hart D, Skerrow C, Roberts RJ, Onions DE (1991) Spontaneously production C-type retrovirus infection of fish cell lines. J Gen Virol 72:2537-2539

Ginsberg HS (1988) Reoviruses and epidemic acute gastroenteritis viruses. In: Dulbecco R, Ginsberg HS (eds) Virology, 2nd edn. JB Lippincott Company, Philadelphia, p 307-319

Gomatos PJ, Tamm I, Dales S, Franklin RM (1962) Reovirus type 3: physical characteristics and interaction with $\mathrm{L}$ cells. Virology 17:441-454

Gorman BM (1979) Variation in orbiviruses. J Gen Virol 44: $1-15$

Gorman BM, Taylor J, Walker PJ (1983) Orbiviruses. In: Joklik WK (ed) Reoviridae. Plenum Press, New York, p 287-357

Hames BD, Rickwood D (1990) Gel electrophoresis of proteins: a practical approach, 2nd edn. Oxford University Press, Oxford

Hayat MA (1989) Principles and techniques of electron microscopy: biological applications, 3rd edn. Macmillan Press, London

Hedrick RP, Rosemark R, Aronstein D, Winton JR, McDowell $\mathrm{T}$, Amend DF (1984) Characteristics of a new reovirus from channel catfish (Ictalurus punctatus). J Gen Virol 65(9): 1527-1534

Hetrick FM, Samal SK, Lupiani B, Dopazo C, Subramanian K, Mohanty S (1992) Members of the family Reoviridae found in aquatic animals. In: Kimura T (ed) Proceedings of the OJI International Symposium on Salmonid Diseases. Hokkaido University, Sapporo, p 33-40
Holmes IH (1983) Rotaviruses. In: Joklik WK (ed) Reoviridae. Plenum Press, New York, p 360-423

Hsu YL, Chen BS, Wu JL (1989) Characteristics of a new reolike virus isolated from landlocked salmon (Oncorhynchus masou Brevoort). Fish Pathol 24(1):37-45

John KR, Richards RH (1999) Characteristics of a new birnavirus isolated from a warmwater fish cell line. J Gen Virol 80:2061-2065

Joklik WK (1983a) The Reoviridae. Plenum Press, New York

Joklik WK (1983b) The members of the family Reoviridae. In: Joklik WK (ed) The Reoviridae. Plenum Press, New York, p 1-7

Joklik WK (1983c) The reovirus particle. In: Joklik WK (ed) The Reoviridae. Plenum Press, New York, p 9-106

Kalica AR, Theodore TS (1979) Polypeptides of simian rotavirus (SA-11) determined by a continuous polyacrylamide gel electrophoresis method. J Gen Virol 43:463-466

Karnovsky MJ (1965) A formaldehyde-glutaradehyde fixative of high osmolarity for use in electron microscopy. J Cell Biol 27:137-138

Kawamura H, Shimizu F, Maeda M, Tsubahara H (1965) Avian reovirus: its properties and serological classification. Natl Inst Anim Health Q 5(3):115-124

Kuchler RJ (1977) Biochemical methods in cell culture and virology. Dowden, Hutchinson \& Ross, Inc, Stroudsburg, PA

Laemmli UK (1970) Cleavage of structural proteins during assembly of the head of bacteriophage T4. Nature 227: $680-685$

Lilley JH, Frerichs GN (1994) Comparison of rhabdoviruses associated with epizootic ulcerative syndrome (EUS) with respect to their structural proteins, cytopathology and serology. J Fish Dis 17:513-522

Lupiani B, Dopazo CP, Ledo A, Fouz B, Barja JL, Hetrick FM, Toranzo AE (1989) New syndrome of mixed bacterial and viral etiology in cultured turbot Scophthalmus maximus. J Aquat Anim Health 1(3):197-204

Lupiani B, Subramanian K, Samal SK (1996) Aquareoviruses. Annu Rev Fish Dis 5:175-208

Marshall SH, Samal SK, McPhillips TH, Moore AR, Hetrick FM (1990) Isolation of a rotavirus from smelt, Osmerus mordax (Mitchell). J Fish Dis 13:87-91

Meyers TR (1979) A reo like virus isolated from juvenile American oysters (Crassostrea virginica). J Gen Virol 43(1): 203-212

Murphy FA, Faquet CM, Bishop DHL, Ghabrial SA, Jarvis AW, Martelli GP, Mayo MA, Summers MD (1995) Virus taxonomy: classification and nomenclature of viruses, Sixth report of the International Committee of Taxonomy of Viruses. Springer-Verlag, New York

Nibert ML, Schiff LA, Fields BN (1996) Reoviruses and their multiplication. In: Fields BN, Knipe DM, Howely PM, Chanock RM, Melnick JL, Monath TP, Roizman B, Straus SE (eds) Fields virology, Vol 2, 3rd edn. Lippincott-Raven, Philadelphia, p 1557-1596

Plumb JA, Bowser PR, Grizzle JM, Mitchell AJ (1979) Fish viruses: a double-stranded RNA icosahedral virus from a North American cyprinid. J Fish Res Board Can 36: 1390-1394

Reynolds ES (1963) The use of lead citrate at high pH as an electron-opaque stain in electron microscopy. J Cell Biol $17: 208-212$

Roberts RJ, Frerichs GN, Tonguthai K, Chinabut S (1994) Epizootic ulcerative syndrome of farmed and wild fishes. In: Muir JF, Roberts RJ (eds) Recent advances in aquaculture, Vol 5. Blackwell Science Ltd, Oxford, p 207-239

Rosen L (1979) Reoviruses. In: Lennette EH, Schmidt NJ (eds) 
Diagnostic procedures for viral and rickettsial infections. American Public Health Association, New York, p 577-584 Rovozzo GC, Burke CN (1973) A manual of basic virological techniques. Prentice Hall, Inc, Englewood Cliffs, NJ

Roy P (1996) Orbiviruses and their multiplication. In: Fields BN, Knipe DM, Howely PM, Chanock RM, Melnick JL, Monath TP, Roizman B, Straus SE (eds) Fields virology, Vol 2, 3rd edn. Lippincott-Raven, Philadelphia, p 1709-1734

Samal SK, Dopazo CP, McPhillips TH, Baya A, Mohanty SB, Hetrick FM (1990) Molecular characterization of a rotavirus-like virus isolated from striped bass (Morone saxatilis). J Virol 64(11):5235-5240

Samal SK, Dopazo CP, Subramanian K, Lupiani B, Mohanty SB, Hetrick FM (1991a) Heterogeneity in the genome RNAs and polypeptides of 5 members of a novel group of rotavirus-like viruses isolated from aquatic animals. J Gen Virol 72:181-184

Samal SK, Subramanian K, Lupiani B, Mohanty SB, Hetrick FM (1991b) Characterization of structural and non-structural proteins of an aquatic rotavirus. In: Fryer JL (ed) Proceedings of the Second International Symposium on Viruses of Lower Vertebrates. Oregon State University, Corvallis, OR, p 243-251

Sambrook J, Fritsch EF, Maniatis T (1989) Molecular cloning. A laboratory manual. Cold Spring Harbor Laboratory Press, New York

Shatkin AJ, Sipe JD, Loh P (1968) Separation of ten reovirus genome segments by polyacrylamide gel electrophoresis. J Virol 2(10):986-991

Editorial responsibility: Jo-Ann Leong,

Corvallis, Oregon, USA
Smith RE, Zweerink HJ, Joklik WK (1969) Polypeptide components of virions, top component and cores of reovirus type 3. Virology 39:791-810

Subramanian K, McPhillips TH, Samal SK (1994) Characterzation of the polypeptides and determination of genome coding assignments of an aquareovirus. Virology 205:75-81

Varner PW, Lewis DH (1991) Characterization of a virus associated with head and lateral line erosion syndrome in marine angelfish. J Aquat Anim Health 3:198-205

Watson ML (1958) Staining of tissue sections for electron microscopy with heavy metals. J Biophys Biochem Cytol $4: 475-478$

Weiner JR, Joklik WK (1989) The sequences of the reovirus serotype 1, serotype 2 and serotype 3 L1 genome segments and analysis of the mode of divergence of the reovirus serotypes. Virology 169(1):194-203

Winton JR, Lannan CN, Fryer JL, Kimura T (1981) Isolation of a new reovirus from chum salmon in Japan. Fish Pathol 15(3/4):155-162

Winton JR, Lannan CN, Fryer JL, Hedrick RP, Meyers TR, Plumb JA, Yamamoto T (1987) Morphological and biochemical properties of four members of a novel group of reoviruses isolated from aquatic animals. J Gen Virol 68(2):353-364

Winton JR, Arakawa CK, Lannan CN, Fryer JL (1989) Isolation of a reovirus from coho salmon (Oncorhynchus kistuch) in Oregon USA. In: Ahne W, Kurstak E (eds) Viruses of lower vertebrates. Springer-Verlag, Heidelberg, p 257-269

Submitted: December 31, 2000; Accepted: March 28, 2001

Proofs received from author(s): September 6, 2001 